UDC 343.137.32

DOI https://doi.org/10.32849/2663-5313/2021.7.13

Oleksandr Vereshchak,

Postgraduate Student at the Department of Criminal Procedure, National Academy of Internal Affairs, 1, Solomianska square, Kyiv, Ukraine, postal code 03035, oleksandr.vereshchak.int@gmail.com ORCID: orcid.org/0000-0003-3895-7337

Vereshchak, Oleksandr (2021). International practice of criminal proceedings in the form of in absentia. Entrepreneurship, Economy and Law, 7, 85-90.

\title{
INTERNATIONAL PRACTICE OF CRIMINAL PROCEEDINGS IN THE FORM OF IN ABSENTIA
}

Abstract. The purpose of the article is to generalize international law and current criminal procedure legislation, the practice of its application and special literature, as well as to highlight the main issues regarding the implementation of a special pre-trial investigation of criminal proceedings. Methodologically, the paper relies on the dialectical method of cognition, general methods of analysis and synthesis, induction and deduction, analogies and comparisons, systems approach in the analysis of legal relations and legal documents, formal logical and comparative legal methods of interpreting law used both at theoretical and empirical levels. Results. Based on the criminal procedural legislation of Ukraine and foreign states, international legal acts, the practice of the European Court of Human Rights, and the current state of development of criminal procedural law, the article conducted a comparative study of the legal regulation of pre-trial investigation in the absence of a suspect (in absentia) in accordance with the criminal procedural legislation of Ukraine and European countries, which includes new and improved scientific conclusions and provisions. It is analyzed the development of European legislation on pre-trial investigation in the absence of a suspect as a component of criminal proceedings in absentia and the possibilities of approximation of Ukrainian criminal procedure legislation in the absence of a suspect (in absentia) to European standards based on the best components of European Union law, case law of the European Court of Human Rights, in particular on the implementation of the provisions of the Convention for the Protection of Human Rights and Fundamental Freedoms. The article analyzes common and distinctive features of special pre-trial investigation in Ukraine and European countries, as well as the specifics of law enforcement with separation of areas of concern of different countries, and the expediency of statutory borrowings of legal norms from criminal proceedings of European countries into criminal procedural law. Attention is drawn to the process of legislative changes that the institution of special pre-trial investigation has undergone recently, in particular, in the context of compliance with the analyzed provisions of European and Commonwealth of Independent States' legislation, and common and distinctive features in trends towards legislative regulation of in absentia proceedings in Ukraine and other countries. Conclusions. Despite the fact that the general practice of using the institute of special pre-trial investigation corresponds to the norms of international legal documents and is close in principles to the experience of foreign states, there is a need for some legislative and methodological improvement taking into account the examples studied in the article.

Key words: special pre-trial investigation, absence of a suspect, trial in absentia, criminal procedural legislation of Ukraine and European countries, experience of trial in absentia in European countries.

\section{Introduction}

The introduction and expansion of the use of the institution of special pretrial investigation in Ukraine should take into account the provisions of basic international legal acts in the field of criminal justice in absentia, as well as the best practices of the Council of Europe Member States and the Commonwealth of Independent States.

In October 2014, the Law of Ukraine "On Amendments to the Criminal and Criminal Procedure Codes of Ukraine concerning the inevitability of punishment for certain crimes against the fundamentals of national security, public security and corruption crimes" was signed. The purpose of this law is to ensure the principle of inevitability of punishment in cases where the suspect (accused), being outside Ukraine, hides from the investigation and court, evading criminal liability, and to increase the effectiveness of investigations of crimes against national security and public safety, as well as ensuring the confiscation of property for their commission. The proposed changes were due to the lack of a procedure in in the legislation in force at that time to prosecute persons who evade 
coming to the pre-trial investigation or court. The existence of such gaps leads in practice to the impossibility of ensuring the implementation of the principle of inevitability of criminal punishment and adequately protect the public interests of the state and the rights of victims of criminal offenses.

A special pre-trial investigation (in absentia) is carried out against one or more suspects in accordance with the general rules of pre-trial investigation provided by the CPC of Ukraine.

A special pre-trial investigation is exercised on the basis of a decision of an investigating judge in criminal proceedings concerning a limited list of crimes (crimes against the fundamentals of national security - Articles 109-114; crimes against public security - Articles 255-258-5; crimes against peace, security of mankind and international law - Articles 436-447; crimes against human life and health - Articles 115, 116, 118, part 2 of Article 121, part 2 of Article 127; crimes against the will, honor and dignity of a person - parts 2 and 3 of Article 146, Article 146-1, Article 147; crimes against property - part 2-5 of Article 191 (in case of official's abuse of his official position); commercial crimes - Article 209; crimes against public authorities, public formations - Article 348; crimes in the sphere of official and professional activity - Articles 364-365-2, Articles 368-370; crimes against justice - Article 379, 400; crimes of servicemen - Article 408) in respect of a suspect, other than a minor, who is hiding from the investigation and court in the temporarily occupied territory of Ukraine, in the territory of the state recognized by the Verkhovna Rada of Ukraine as an aggressor state, in order to evade criminal responsibility and/or declared internationally wanted.

Special pre-trial investigation of other crimes is not allowed, except when the crimes were committed by persons hiding from the investigation and court in the temporarily occupied territory of Ukraine, the state recognized by the Verkhovna Rada of Ukraine as an aggressor state to avoid criminal liability and/or they are internationally wanted and are being investigated in the same criminal proceedings as the offenses set forth in part 2 of Article 297-1 of the CPC, and the release of materials concerning them may adversely affect the completeness of the pre-trial investigation and trial.

If several persons are notified of a suspicion in criminal proceedings, the investigator, prosecutor has the right to apply to the investigating judge with a request to conduct a special pre-trial investigation only in respect of those suspects in respect of whom there are grounds envisaged by part 2 of Article 297-1; in respect of other suspects, further pre-trial investigation in the same criminal proceedings will be carried out in accordance with the general rules provided by the CPC of Ukraine (Criminal Procedure Code of Ukraine, 2021).

The study of individual challenging issues related to the special pre-trial investigation is relevant and necessary as this institution can be considered new. Thus, it needs improving and borrowing practical experience from other countries. The scientific works of Yu. Azarov, D. Alekseev-Protsiuk, A. Barabash, V. Drozd, O. Kuchynska, L. Loboyko, V. Maliarenko, M. Markusha, M. Mykheenko, O. NahorniukDanyliuk, V. Nor, R. Piestsov, P. Pylypchuk, D. Pysmenny, O. Tatarov, S. Shmalenia and others are devoted to specific issues concerning the special pre-trial investigation.

2. Compliance of the institute of special pre-trial investigation in Ukraine with international legal acts

Introduction of pre-trial investigation in absentia into the domestic criminal proceedings generally corresponds to the norms of international legal acts.

In law enforcement activities, there are often cases when the tasks of criminal proceedings, which are defined in Article 2 of the CPC of Ukraine, are not implemented due to the evasion of a person from coming to the pre-trial investigation or court that makes it impossible to prosecute and, consequently, violates the principles of criminal proceedings on the inevitability of criminal punishment, rule of law, equality before the law and court and others.

Reducing the time and simplification of criminal proceedings is one of the main trends in the development of criminal procedural law in Western countries, which was formed due to the growing number of criminal proceedings in courts and inconveniences arising from the length of proceedings.

The introduction of the institute of special pre-trial investigation of criminal offenses has long become a necessity in the context of approximation of Ukrainian criminal procedure legislation to the norms of the Convention for the Protection of Human Rights and Fundamental Freedoms. According to world practice, trials in absentia are used in some countries - members of the Council of Europe and the CIS. At the same time, this type of proceedings is aimed at implementing the principle of inevitability of criminal liability for a committed crime.

In addition, even the 1960 CPC provided for the possibility of considering a case in the absence of the defendant, if the latter was outside Ukraine and evaded appearing in court (Part 1 of Article 262).

Introduction of trial in absentia into domestic criminal proceedings generally corresponds to the norms of international legal 
acts. Thus, the provisions of paragraph 9 (a) of Section 3 of Recommendation № R (87) 18 of the Committee of Ministers of the Council of Europe require Member States to consider and allow the courts of first instance to hear cases and make decisions in the absence of the accused, provided that the latter is duly informed of the date of the hearing and of his right to legal or other representation.

The rules on criminal proceedings in absentia are also consistent with the content of Resolution № 75 (11) of the Committee of Ministers of the Council of Europe on the criteria governing proceedings in the absence of the accused.

3. Comparison with the experience oftheCouncilofEuropeand the Commonwealth of Independent States

Some experience of implementing the institute of special pre-trial investigation in France, the Netherlands, Denmark, Estonia, Moldova, Russia, Bulgaria and Lithuania can be taken into consideration during further amendments of its provisions in Ukraine.

The institute of trial in absentia has long been operating in such countries as France, Switzerland, Denmark, Estonia, Russia, Great Britain and many others where it has proven its effectiveness and expediency.

For example, the French CPC stipulates that trial in absentia is possible towards any person who is duly summoned to court but does not appear at the appointed time, in minor cases, in cases of crimes and offenses.

The Netherlands also provides for criminal proceedings in the absence of a defendant. The defendant is not required to be present at the trial. In case of his non-appearance, the court, having established the fact of his proper notification, considers the criminal case in absentia. The same practice takes place when the defendant notifies of his non-appearance and requests a postponement of the trial, when he maintains the defense in writing and even when he does not appear in court for reasons beyond his control. A convict who has been sentenced in absentia has the right to appeal against it by filing a protest. In this case, the same court reconsiders the case and renders a new verdict.

In Danish criminal proceedings, the accused is not obliged to appear in court at all. In case of non-appearance of the defendant, the defense counsel is allowed to represent his interests, if the reasons for such absence are valid.

According to Part 2 of Article 269 of the CPC of Estonia, as an exception, the trial of a criminal case may be conducted without the participation of the accused, if he:

- is removed from the courtroom for violation of the court procedure;

- is outside the country and evades appearing in court, and trial in the absence of the accused is possible;
- has brought himself, after questioning in court, to a state which precludes his participation in the hearing, and trial in his absence is possible;

- the delivery of the accused is complicated and he agrees to participate in the trial in audiovisual form.

This institution is relatively "young" in the CIS countries, the implementation practice of which was directly studied by the author.

In particular, according to Article 321 of the CPC of Moldova, the consideration of the case in the absence of the defendant may be carried out if: the defendant evades appearing in court; the defendant, who is being held in custody, refuses to appear before the court for consideration of the case and such refusal is confirmed by his defense counsel; it is a matter of committing minor crimes and the defendant expressed a wish for the trial to be held in his absence.

According to the CPC of the Russian Federation, a trial in the absence of a defendant is also possible if in a criminal case of a crime of small or medium gravity, the defendant initiates a motion for its consideration in his absence. The consideration of serious and especially serious crimes is possible only in exceptional cases: if the defendant is outside of Russia and (or) evades appearing in court, and if the person has not been prosecuted in a foreign country in this criminal case (Tatarov, 2015).

Among the European states prescribing a pre-trial investigation in the absence of a suspect or accused, which has common features with the criminal proceedings under the CPC of Ukraine, one can mark the Republic of Bulgaria, the Republic of Lithuania, and the Czech Republic.

The criminal proceedings of Bulgaria and Ukraine, despite their peculiarities, have one thing in common - the availability of a pretrial investigation in absentia and the mandatory participation of counsel in such proceedings that makes it possible to compare them by examining their differences.

A comparative analysis of the criminal procedure legislation of the Republic of Lithuania and Ukraine allows the author to identify the following features: crimes which include pre-trial investigation in absentia are not identical but are similar in a separate part (in particular, crimes against humanity, war crimes and crimes related to terrorism); in accordance with the CPC of the Republic of Lithuania, the investigating judge, unlike the CPC of Ukraine, does not make a separate procedural decision to conduct a pre-trial investigation in the absence of the suspect but, in certain cases, decides to recognize a person as a suspect; defense counsel participates in the pre-trial investigation in absentia following the CPC under study; in 
accordance with the CPC of the Republic of Lithuania, pre-trial investigation in absentia, in contrast to the CPC of Ukraine, cannot be carried out if the suspect is not in the territory of the state or the whereabouts of the suspect are not known at all; the procedure for notifying a person who is in hiding or whose whereabouts are unknown has significant differences; during the pretrial investigation in absentia, the suspect, under the CPC of the Republic of Lithuania compared to the CPC of Ukraine, is notified of the completion of the pre-trial investigation and is sent an indictment, including by mail and in the order of international cooperation.

5. Analysis of the case law of the European Court of Human Rights in the application of the procedure in absentia in different countries

Taking into account the practice and positions of the European Court of Human Rights when amending the current legislation prevents noncompliance with the guarantees of a fair criminal procedure under the in absentia procedure.

Amendments to Ukrainian law are an important step in ensuring that the case is properly investigated in absentia and heard in court. This will prevent or significantly reduce the defendants' appeal to the European Court of Human Rights, the practice of which the author considers hereafter.

The European Court of Human Rights allows the possibility of criminal proceedings in absentia provided that the rights and freedoms established by the Convention are ensured. In particular, in the decision "Da Lus Dominges Ferreira v. Belgium", the ECHR stated that a court hearing in the absence of a defendant does not in itself constitute a violation of Article 6 of the Convention. At the same time, denial of access to justice occurs when a person convicted in absentia cannot obtain a new court decision on the validity of the accusation on factual and legal grounds after it has been implemented, unless it has been established that this person has waived his/her right for defense and appearance in court (Information resource "Practice of the European Court of Human Rights. Ukrainian aspect").

The ECHR also recognized violation of Article 6 of the Convention in the case "Somogyi v. Italy". The decision notes that although this is not explicitly stated in $\S 1$ of Article 6, the subject and purpose of the Article in general provides for the right of the accused to participate in the trial. Even more, paragraphs "c", "d" and "e" § 1 of Article 6 guarantee everyone accused of committing a criminal offense the opportunity to defend themselves personally, interrogate witnesses and receive free assistance from an interpreter.

According to the position of the ECHR, violation of at least one of the principles (to be informed about the accusation; to be represented by a defense counsel; to participate in the case; to a new trial, to waive his right to be present at the trial) leads to non-compliance with guarantees of fair criminal proceedings under the procedure "in absentia".

Therefore, when making further changes and additions to the current legislation, the author considers necessary to pay more attention to the practice and positions of the ECHR which, in turn, will contribute to the proper implementation of criminal proceedings, as well as prevent noncompliance with the guarantees of a fair criminal procedure under the "in absentia" procedure.

\section{Conclusions}

Despite the fact that the general practice of using the institute of special pre-trial investigation corresponds to the norms of international legal documents and is close in principles to the experience of foreign states, there is a need for some legislative and methodological improvement taking into account the examples studied in the article.

Summarizing the above mentioned, the author highlights that the procedural legislation of foreign countries envisages the procedure of a trial in absentia without the participation of the suspect or accused. It is important that they are provided with procedural guarantees for the defense and appeal of both court decisions and decisions of pre-trial investigation bodies.

Today, pre-trial investigation in absentia has a short practice of its application in our country, but legislators continue to make changes to the current CPC of Ukraine. The Verkhovna Rada of Ukraine once again provided an opportunity for the legal community to actively participate in heated discussions on innovations in the national legal space. This time, the law on absentee conviction became the hot-bottom topic of public and professional discussion. On April 27, 2021, the Parliament voted for the draft law № 2164 "On amendments to the Criminal Procedure Code to improve certain provisions due to the implementation of a special pre-trial investigation".

Therefore, the author hopes that these and other changes will further facilitate the implementation of criminal proceedings under the "in absentia" procedure in Ukraine and meet the best European standards.

In each case, the special procedure of criminal proceedings in the absence of the accused is a complex process of observing the "balance of interests of the state and the accused". Both representatives of the judiciary and law enforcement agencies and the entire legal community of Ukraine should try to achieve such a balance and overcome possible risks, because the respect of human and civil rights and strengthening Ukraine's image as the rule-of-law state depends on all stakeholders (Zakirova, 2021, p. 14). 


\section{References:}

Kodeks kryminalnyi protsesualnyi vid 13.04.2012 № 4651-VI zi zminamy ta dopovnenniamy vid 01.07.2021 [Criminal Procedure Code of Ukraine: Law of Ukraine of April 13. 2012 with changes and additions as of 01.07.2021]. ips.ligazakon.net. Retrieved from: https://ips.ligazakon.net/document/t124651?an=1 (in Ukrainian).

Koly zaochne zasudzhennia porushuie pravo na spravedlyvyi sud [When a conviction in absentia violates the right to a fair trial] echr.com.ua. Retrieved from: https://www.echr.com.ua/koli-zaochne-zasudzhennyaporushuye-pravo-na-spravedlivij-sud/ (in Ukrainian).

Tatarov, O. (2015). Zaochnyy rozhlyad ochyma Yevropy [Correspondence examination through the eyes of Europe]. zib.com.ua. Retrieved from: https://zib.com.ua/ua/print/114635-7_vimog_espl_do_zaochnogo_ provadzhennya.html (in Ukrainian).

Zakirova, S. (2021). Kryminal ne provadzhennya za protseduroyu «in absentia»: ukrayins ki novatsiyi ta mizhnarodnyy dosvid [Criminal proceedings under the "in absentia" procedure: Ukrainian innovations and international experience]. Hromads ka dumka pro pravotvorennya - Public opinion on lazomaking, 9 (214) (in Ukrainian)

\section{Олександр Верещак,}

аспірант кафедри кримінального прочесу, Національна академія внутрішніх справ, площа Солом'янська, 1, Київ, Україна, індекс 03035, oleksandr.vereshchak.int@gmail.com

ORCID: orcid.org/0000-0003-3895-7337

\section{МІЖНАРОДНА ПРАКТИКА ЗДІЙСНЕННЯ КРИМІНАЛЬНОГО ПРОВАДЖЕННЯ У ФОРМІ IN ABSENTIA}

Анотація. Метою роботи є узагальнення міжнародного законодавства, чинного вітчизняного кримінального процесуального законодавства та практики його застосування, а також спеціальної літератури щодо здійснення спеціального досудового розслідування кримінального провадження. Методологічно робота заснована на діалектичному методі пізнання, на загальних прийомах аналізу й синтезу, індукції та дедукції, на виявленні аналогій і проведенні порівнянь, на системному підході в аналізі правових відносин та юридичних документів, на формально-логічному й порівняльноправовому методах тлумачення права, використовуваних як на теоретичному, так і на емпіричному рівнях. Результати. На основі кримінального процесуального законодавства України та іноземних держав, міжнародних правових актів, практики Європейського суду з прав людини, аналізу сучасного стану розвитку кримінального процесуального права у статті проведено порівняльне дослідження правового регулювання процедури досудового розслідування за відсутності підозрюваного (in absentia) згідно з кримінальним процесуальним законодавством України та країн Європи, що включає нові й удосконалені наукові висновки та положення. Проаналізовано розвиток законодавства країн Європи щодо досудового розслідування за відсутності підозрюваного як складової частини кримінального провадження in absentia та з'ясовано можливості наближення українського кримінального процесуального законодавства за відсутності підозрюваного (in absentia) до європейських стандартів на основі кращих складників розвитку права Європейського Союзу, практики Європейського суду з прав людини, зокрема, щодо виконання положень Конвенції про захист прав людини і основоположних свобод. Охарактеризовано спільні й відмінні риси здійснення спеціального досудового розслідування в Україні та країнах Європи, а також специфіку правозастосування, виокремлено актуальні проблемні питання для різних країн, а також розглянуто доцільність нормативних запозичень у вітчизняний кримінальний процесуальний закон правових норм із кримінальних процесів країн Європи. Звернено увагу на процес законодавчих змін, яких зазнає інститут спеціального досудового розслідування впродовж останнього часу, зокрема, у контексті відповідності проаналізованих положень законодавству країн Європи та Співдружності Незалежних Держав, а також щодо спільних і відмінних рис у тенденціях стосовно законодавчого унормування заочного провадження в Україні та інших країнах. Висновки. Незважаючи на те, що загальна практика застосування інституту спеціального досудового розслідування відповідає нормам міжнародноправових документів та за принципами близька до досвіду іноземних держав, $є$ потреба в певному законодавчому й методичному вдосконаленні з урахуванням досліджених у статті прикладів.

Ключові слова: спеціальне досудове розслідування, відсутність підозрюваного, заочне кримінальне провадження, кримінальне процесуальне законодавство України та країн Свропи, досвід заочного кримінального провадження країн Європи. 